\title{
The History and Origin of Fraud as a Defect in Consent in Contractual Relationships
}

\author{
Egzonis Hajdari
}

\author{
Faculty of Law, AAB College, Kosovo \\ Email: egzonishajdari@gmail.com
}

\section{Submitted : 2020-03-29 | Accepted : 2021-04-26}

\begin{abstract}
Fraud is a specific type of defect in consent that manifests the purpose of one of the parties to establish a contractual relationship through deceptive actions. As such, fraud is an unlawful and unethical action that emerged beginning with some of the earliest agreements in human society. Moreover, the practical treatment of fraud is likely to have occurred since the genesis of its appearance. More appropriate and advanced treatment of fraud can be seen after the implementation of the first legal systems, which focused on contractual relationships. Fraud in contractual relationships will be examined starting with Babylonian, Ancient Greek, Roman, and Islamic law and will continue with a focus on Albanian customary law and modern laws implemented in Kosovo. Furthermore, in this article, also explained how the treatment of fraud has evolved in the legal framework in Kosovo.
\end{abstract}

Keywords: fraud; islamic law; ancient greek law; roman law; kosovo customary law.

\section{INTRODUCTION}

History tells us of contractual relationships between parties since the ancient world. From different points of view, researchers have related the genesis of these contractual relationships to the creation and development of human society. Initially, such relationships were created and developed as a necessity of existence, then as a necessity for the transformation and development of human society up to the present day. However, within these contractual relations have also appeared unfair acts that have disregarded the intended equality and legality; such unfair acts mainly refer to defects in consent, including duress, mistake, and fraud.
Defects in consent were faced within the aspect of their practical handling, at the same time of their presence. Their conduct, with a focus on fraud, as seen in the practical (and even legal) aspects, has shown a marked development since the emergence of the first legal systems. Today, their regulation has taken on a different dimension in scientific terms. Moreover, we will briefly talk in general about the history of fraud in contractual relationships, and then the history of this unlawful act in Turkey and Kosovo.

This paper is structured as follows. Initially, fraud under the Babylonian, ancient Greek, Roman, and Islamic law will be described, followed by Old Turkish law, customary Albanian law, and Law on 
Obligational Relationships of the Former Yugoslavia. All of this will be analyzed based on trusted legal literature, and conclusions will be presented at the end of the paper.

To achieve relevant scientific results, it is necessary to approach this issue through an analysis, descriptive, and comparative means as well.

\section{LEGAL MATERIALS METHOD}

AN

This research paper adopted normative judicial method which examine and analysis legal sources regarding frauds and history of frauds. This paper is also use descriptive and comparative method to get better understanding regarding the purpose of the research. Relevant journal and books are also used to support and strengthen this paper academic argument.

\section{RESULTS AND DISCUSSIONS Fraud in Babylonian Law}

In Babylon, the law of obligation was empirical right, informal, and based on unilateral logic. While on the other hand, the formal contract was only used to make more understandable the scope of legal transactions, and more trustiness as well. The Babylonians did not make abstractions and theoretical - legal deductions at that time, so they did not distinguish between the contractual obligations of those non contracting, or even the obligations arising from the defects in consent. From this point

1 Ismajli, Hilmi and Sejdiu, Fatmir, Historia e shtetit dhe së drejtës I, (Prishtinë, Universiteti i Prishtines, 2005), p. 52

2 Hammurabi's code was the legal act with the main key on these foundations was laid down the general concepts of law in Babylon.

3 Ismajli, above $\mathrm{n} 1$, p. 53

4 The Hammurabi code was written on the basal stone at a $2.25 \mathrm{~m}$ long distance. This code contained 292 articles and its text was discovered of view, it can be concluded that Babylonian law did not recognize the division of the contracts like they were systematized in Roman law: formal, real, and consensual contracts. But this does not mean that there were no contracts in Babylon for which a mandatory had a minimum obligation. ${ }^{1}$ Here we will try to present fraud based on Babylonian law, a topic totally neglected by scholars.

Consequently, in Babylon the majority of contracts were concluded in a simple way, which means it was sufficient to have the free consent from the contractual party's. However, the main forms of contracts under the Hammurabi Code ${ }^{2}$ have been in written form, concluded under free will, and bounded in the presence of witnesses. If the contract form was not filled according to these conditions, it was considered null, because such contracts concluded in oral forms could be difficult, or impossible to prove. $^{3}$

From a scientific point of view that can be made to the Hammurabi Code ${ }^{4}$ it cannot be freely determined that this Code in its solutions did not contain concrete norms regarding the issue of defects in consent in obligational relationships. So, in this Code, it is mentioned the phenomenon of fraud in the obligational relationships of the parties at all. The various cases studied show that fraud, therefore, the acquisition of another's property on the basis of fraud, was considered as an unlawful act, in which case the punishment of the lawbreaker was also

by a team of French archaeologists in 1901/1902 in the ruins of Suzi city, today the southwest coast of Iran, the capital of the former state of Elam; see also: Dragusha, Musa, Kodi i Hamurabit, nje monument $i$ traditës juridike të njerëzimit, (2008) Avokatura, IV(7), p. 12, Buletini I Odës së Avokatëve të Kosovës. Available at: http://www.oakks.org/repository/docs/AVOKAT URA_Nr.7_687807_286246.pdf. 
done. Legal documents, stamps, animal ownership stamps, slave marks, and measuring instruments were considered methods of fraud committed by a person. ${ }^{5}$

In fact, the Hammurabi Code deceit had, directly and indirectly, addressed fraud at some points, considering it illegal. According to an analysis and research carried out in this Code and practical cases, fraud as unlawful conduct had taken place into Art's. 05, 11, 13, 34, 103, 106, 107, 108, 109, 114, 155, 156 and 265. Thus, the compensation of the damages in some cases also foresaw the possibility of a "death penalty" 6 , for persons who were guilty of acting fraudulently.

\section{Fraud in the Ancient Greek Law}

Ancient Greece originated from the city-states called "polis", which were created as a result of the economic and social development of the population, included the influence of the ancient near east civilization. In ancient Greece, there was about two hundred (200) polis with similarities and obvious differences between each other. ${ }^{7}$ During this period of time in Ancient Greece there were improvements in the development of the laws and legal institutions. Ancient Greek law has begun with the Athenian Code

\footnotetext{
Badamchi, Hossein, 'Fraud and Forgery in Old Babylonian Law', Wiesbaden, (2016) 22 Journal For Ancient Near Eastern an Biblical Law, p.21 Available https://www.academia.edu/33033088/Fraud_and Forgery_in_Old_Babylonian_Law_in_Zeitschrift _für_Altorientalische_und_Biblische_Rechtsgesc hichte

6 There are thoughts that conforming to Hammurabi's Code about the committed fraud, in case of this, the person who deceived another one may be punished with death decision. See also: Holden, George, Code of Hammurabi, the Important Laws of Our Time, November, 2015, p. 5 Available at: http://www.epcc.edu/HonorsProgram/Student $\% 2$ OProjects/M_Chavez-

North_Code\%20of\%20Hammurabi\%20the\%20i mportant\%20laws\%20of\%20our\%20time\%20(A PA).pdf
}

from the IV and V centuries, while the basic of civil code was taken from so-called "Basilica". 8

As noted from the literature there is a lack of evidence showing that in Ancient Greek Law fraud as unfair behavior or any other forms of a defect in consent was unknown through the conclusion of the contracts. "This ancient law, such as Babylonian Law, did not make any difference (as did the Roman law) between "actio in rem" and "actio in personam", also it did not differentiate the "summa division" made by "Gaius" between the "obligationes ex delicto" and the "obligationes excontractu". But, when the obligation was created, either by contract or by offense, it was respected with greater seriousness. ${ }^{9}$ This rule was also applied through the concluding of the contracts that could be characterized by a defect in consent. This is because the contract was considered as the law between the contractual parties. At this period of time, during the formation of the contract, no particular formalism or symbolism was required. It was enough for the contracting party's to freely express their consent (will) on the essential elements of the contract. ${ }^{10}$ This means that the contract was valid even

7 Ismajli, above n 1, p 69-70

8 The "Basilica" was a collection of laws completed in Constantinople by the order of the Byzantine Emperor Leo VI during the Macedonian dynasty. It was a continuation of the work begun by his father, Basil I, to adapt and simplify the Corpus Juris Civilization Code of Emperor Justinian I, issued between 529-534 years, and which was outdated. The term "Basilica" does not come from the name of Emperor Basil I, but from the Greek language " $\tau \grave{\alpha} \beta \alpha \sigma l \lambda l \kappa \alpha$ ”, which means "monarchy laws".

9 Ismajli, above n 1, p. 88

10 Ţuțuianu Ion, 'Legal regulation of the obligations in old romanian law', greek and roman, (2012) Studies and Scientific Researches Economics Edition, No. 16-17, Available at:: http://sceco.ub.ro/index.php/SCECO/article/view/ $74 / 74$ 
when it was concluded in oral form. So the written form was not a necessary condition for its validity.

The ancient Greek law has considered the issue of defects in consent in obligational relationships relatively late. Consequently, the treatment of these phenomena was initially of a superficial nature, ${ }^{11}$ and gradually they took the right dimensions of elaboration. In fact, the phenomenon of fraud and other defects in consent in concluding contracts in ancient Greek law in a superficial sense is first encountered in the "Dragon law"12 and "Solon law"13 in Athens, and probably also in the "laws of Lycurgus" 14 in Sparta. In these circumstances created by the issuance of these laws and upcoming laws, the Greek law in general, and Athenian law, in particular, were rigorous to the irresponsible party's in obligational relationships. ${ }^{15}$ Such individuals could be prosecuted and forced to compensate for the damage they caused, ${ }^{16}$ same as it was stipulated under Babylonian Law. Under the ancient Greek law, fraud in obligational relationships was considered to exist when, for example, the buyer had entered into a contract with the seller for the purchase of a shop store, which in the transfer of property

11 This includes also the time of Homer's activity, which was considered a master of science and wisdom. He had the absolute authority in all areas that gave to the Greeks the unity and culture of the nation.

12 Dragon's laws for most legal problems, including contracts, contained a very harsh solution. The fraudulent conduct made in the contractual relationships was defined as criminal offenses. Meanwhile, Solomon's laws had marked a higher degree of delivery to more pragmatic solutions. In relation to fraud, the focus was directed towards compensation for damage, even though these laws dealt with essential fraud as criminal offenses.

13 Athens and Sparta were the most popular Greek poles. They were so because they had the highest degree of economic and social development, dictated by the geographical position and also based on the intellectuals of that time. rights, and the owner was found to be lawless of that property. Such of contract, the deceived party has a right to rescind the contract concluded under the influence of fraudulent conduct.

As it turns out, the ancient Greek law generally on issues of obligations relationships, with a focus on fraud as a defect in consent, has been an evolution that largely matches with the developments that have characterized other old laws, especially Babylonian Law. This means that the mutual influence of the old laws was quite evident. There must necessarily be a relationship between the trio "adikia - hamartema atuchia" of the ancient Greek law, and the "dolus - culpa - casus" which was found in the old Roman law. ${ }^{17}$

\section{Fraud in the old Roman law}

Roman law "Jus Romanorum" is the legal system of ancient Rome, from the moment of its formation (according to the legend of 754 or $753 \mathrm{BC}$ ) until the death of King Justinian (in year 563 according to our epoch). ${ }^{18}$ Roman law represented the most advanced law of the time. It was a model for other ancient laws. Considering this, Roman laws contained numerous norms on

14 The laws of Lycurgus have not been preserved and little knowledge about them, but they are considered to have been mainly a description of customary law or its reform and change of that right.

15 George, Grote, A History of Ancient Greece Solon's Early Greek Legislation, (Boston, Jhon P. Jewet \& Company, 1851), p.30, Available at:: http://history-world.org/solon.htm

16 Ibid

17 David, Ibbetson, 'Wrongs and Responsibility in Pre-Roman Law', (2004) 25(2) The Journal of Legal History, p. 100, Available at: http://faculty.uml.edu/Ethan_Spanier/Teaching/do cuments/IbbetsonANEWrongs.pdf

18 The Western Roman Kingdom was destroyed in the year 476, but the history of Roman law is considered completed with the death of the Emperor "Justinian". 
personality rights, family and inheritance law, marital and property rights, and obligations law.

In fact, it is considered that ancient Roman law had borrowed a lot from Ancient Greek Law, considering a large number of legal solutions, including those addressing issues of the right to obligations. This finding is based on the fact that at that time in Athens, a lot of Roman lawmakers had migrated, and while returning back home they have taken the model of Greek laws and integrated it into their existing legislation. ${ }^{19}$

In Roman civil law, there was no problem of discrepancy between the declaration and will of the parties. This means that this right has not recognized any form of defects in consent, hence no fraud. "According to the old "jus civile" provisions, every will which is expressed solemnly, regardless of the reasons for which it was expressed, and regardless of whether the parties was a declaration of what they really wanted" 20 . At that time, the contract form had completely vested the will. ${ }^{21}$ This means during this period of time, a party that had entered into a contract in the effect of fraud had neither right for protection nor the right to compensation for the damage caused. $^{22}$

The problem of discrepancy between the declaration and will of the party's, arise when bona fide contracts emerged. Bona fide contracts appear from the time when Roman

19 Bauman, R. A., The interface of Greek and Roman Law, 1996, p. 40, Available at:: http://local.droit.ulg.ac.be/sa/rida/file/1996/04.Ba uman.pdf

20 Ngjela Spartak, E drejta romake, Tiranë, UET, 2000, p.344

21 Puhan Ivo, E drejta romake (translatied in albanian), Prishtinë, 1980, p.311

22 Borkowski Andrew, Plessis du Paul, E Drejta romake (përkthim shqip), Tiranë, Univerziteti i Prishtines, 2009, p.344

23 Bilalli Asllan, Bahtir Bedri, E drejta romake, Prishtinë, Prishtine University, 2015, p.418-419 economic relations dominated the opinion that every legal transaction should be careful about the conditions due to which the contract will be concluded. ${ }^{23}$ Then, it was proved that the parties enter into different legal transactions because of their specific goals, therefore they freely decide to conclude the contract. According to the principles of bona fide, as regular legal contracts, all those contracts were considered valid when the party's knew why and when they were free to decide to enter into the contract. Rather, all those contracts were considered void when the party's did not know what they signing about or were forced to sign the contract. In such cases, there was a discrepancy between the declaration and the will of the party's. Cases of the discrepancy between expression and will of the parties were divided into "reservatio mutatis", "simulatio", "dolus" and "vic ac netus" 24 .

Fraud as a defect in consent after "bona fide" contracts, the Roman law has given particular importance, as demonstrated in a famous slogan "Fides bona contraria est fraudi et dolo" (good faith excludes fraud and dishonesty). ${ }^{25}$ According to Roman law, the owner was responsible not only for fraud but also in case of delays. ${ }^{26}$ "At this time "Fraud (dolus) represented the intention to create a false statement on the other side with the intention of concluding a contract to its

24 Opcit. Puhan, p. 111-112

25 Barbara, Biscotti, Debtor's Fraud In Roman Law An Opportunity For Some Briefremarks On The Concept Of Fraud, Fundamina, (2011) 17(2), p. 9, Available at: https://www.academia.edu/4179151/DEBTOR_S _FRAUD_IN_ROMAN_LAW._AN_OPPORTU NITY_FOR_SOME_BRIEF_REMARKS_ON_T HE_CONCEPT OF_FRAUD

26 Mihai Olariu, Contracts In Roman Law, p. 7, Available $\mathrm{ftp}$ //ftp.repec.org/opt/ReDIF/RePEc/rau/clieui/SP 14/CLI-SP14-A9.pdf 
detriment". ${ }^{27}$ Looking in the context of this approach: ${ }^{28}$

"Fraud (dolus) was the purpose to make the other party have a false statement for the purpose of concluding a contract that was unfavorable to him/her: dolo malo pactum fit, quotiens circumscribendi aliud agitur et aliud agi simulatur. This means that the contract is related to fraud, if the other party behaves in a wiliness manner, acting in a way but doing the contrary. In fact, that the fraud was made with a purpose of changing and blurring the facts - caliditatibus fallaciis et mashinationibus".

The fraud may be caused by one of the contractual party's or by any third person. ${ }^{29}$ Mistake, fraud, duress, and misrepresentation are considered defects in consent in Roman law. ${ }^{30}$ For instance, in cases where the buyer in the jewelry store had expressed an interest in buying a gold watch and the seller has sold him a gold plated watch. Fraud, according to the Roman law "dolus" at the same time was considered as an unlawful conduct as well. According to Ius Civile, furtum (robbery), rapina (burglary), damnum iniuria datum (property damage), iniuria (injury of persons), pretators expanded the illegal acts listing also dolus (fraud), metus (mistake), and fraus creditorum (fraudulent conducts against creditor) as an unlawful act. ${ }^{31}$

According to the literature, fraud (dolus) in Roman Obligation Law existed

27 Selmani, Bashkim and Rexhepi, Bekim, E drejta romake, f. 656-661, Ferizaj, 2014, p.475

28 Ibid, p. 314; see also: Akıncı, Şahin, Roma Hukuku Dersleri, Konya, 2003, p.124

29 Halûk N. Nomer, Borçlar Hukuku Dersleri Genel Hükümler, Istanbul, Beta, 2020, p.44

30 Akınc1, Şahin, above n 28, p.124

31 Since, fraud in Roman law was considered, except as a defect and as an outright act, this right accorded to deceiving different ways of legal protection. See also: Bengi Sayin, Korkmaz, when the fraudulent conducts were expressed at the time when the contract was concluded, even earlier fraudulent conducts. Roman law also made a division of fraud, in "dolus malus" (serious fraud) and "dolus bonus" (easy fraud), which played an important role in the validity of obligational relationships. ${ }^{32}$

Therefore, as for the existence of fraud in Roman obligation law, it was not a necessary condition to ascertain the fact of the existence of the discrepancy between the declaration and the will of the parties. But here a basic condition, was the fact of intentionally inducing the contracting party or a third person to convince the other party of his/her will and to do so would not sign such a contract as if he/she knew all the circumstances.

The juridical protection act for the deceived parties was: exceptio doli, actio doli, and in integrum restitutio. The right of "exceptio doli" 132 was used by people who were mistaken but have not yet done the promised action. Exceptio doli was general (exception doli generalis seu preaesentis) when the deceived person stated that in the relevant contract at the time of conclusion of the contract were no fraudulent acts, but the fulfillment of the contract would be fraud due to later facts. Exceptio doli was special (exceptio doli specialise seu praeteriti) when the injured person stated that deceptive

Roma Hukuku'nda Hile (Dolus) Kavrami, Temmuz, Kirikkale University Journal of Sciences, (2017) 7(2), p. 428, Available at: http://dergipark.gov.tr/download/articlefile/338039;

32 Mihaela, Miruna Tudoraşcu and Alba, Iulia, Paraschiv D. Ion - Good faith to conclusion of the sale, 2009, p.212, Available at: http://www.uab.ro/reviste_recunoscute/reviste_dr ept/annales_12_2009/31tudorascu.pdf 
actions were made at the time that the contract was concluded. ${ }^{33}$

Actio doli was a claim that the person who had fallen into the trick was able to use it against the fraudulent party. He could file this claim within one year from the time the contract was signed. Actio doli was not only a legal protection act for an annulment of the contract, but it was a claim for compensation for the damage and reclaims restitution as well. So, since the actio doli was known as a criminal claim, through it the defendant was forced to pay an amount of money. Thus, the person who caused the fraud was punished (penalized), while on the other hand the deceived person was compensated for the damage that occurred from fraud. Another important effect of this claim, consisted in the fact that the convicted person was, as a rule, given the epithet of a dishonest person. In the upcoming Roman law, this epithet of humiliation was a serious sanction because it also led to the limitation of legal capacity. ${ }^{34}$

Actio doli, because of the effects it could cause, was considered a very serious claim $^{35}$. So the filing of this claim could only take place when there was no other way. ${ }^{36} \mathrm{In}$ this regard, the right to use this act only came from those persons, who had no way of getting back the previous situation. As noted from the above, the deceived party who, even after the "clausula arbitraria" (requesting the item to be handed over to the deceived party), did not hand over the item, was obliged to repay the damage and pronounced an "infamy" person.

"Exceptio doli" and "actio doli" according to the roman law knew a third

\footnotetext{
33 Janjić-Komar M, Korać R, Ponjavić Z. Porodično pravo. Dečje novine; 1994, p. 315

34 Akınc1, Şahin, above n 28, p.125-126

35 Ibid

36 Umur Ziya, Roma hukuku ders notlari, 3 basim, Istanbul, Beta Yayınevi, 2010,0 p. 208

37 Ibid. p. 208-209
}

possibility of returning to the previous state (restitucio in integrum) ${ }^{37}$ Restitution means the allowing of the contracting party to rescind the contract and in cases where it has fulfilled the contractual obligations to claim the returning of the previous state. By returning to the previous situation, the situation had to come to a condition as if that legal transaction had not happened at all. Thus, the assets of the contracting parties behaved in a state that had existed before fraud, through the obligational relationship. ${ }^{38}$

As it turns out the contracts related to fraud in Roman law through the use of these juridical acts (exception doli and actio doli) any legal transaction could be annulled. These were treated as voidable contracts since they "created legal consequences for as long as the other parties did not request the reinstatement of the action or did not reject to the claim that the other party might have done". 39

According to this, we conclude that Roman law has made great progress in regulating fraud, compared to the rights mentioned above. Moreover, Roman law has an indisputable influence on all following rights according to this unlawful act. Plus, Roman law has considered advanced because of regulating the juridical protection act for the deceived parties, contrasted to Babylonian and Greek Law.

\section{Fraud in Islamic Law}

The Islamic law notion is understood as the legal system, which was applicable in Islamic states including the Ottoman Empire, ${ }^{40}$ back in time in the Islamic law, like

38 Akınc1, Şahin, above n 28, p.126-127

39 Mandro Arta, E drejta Romake, Tiranë, 2004, p.267

40 The Ottoman Empire was founded at the beginning of the 14th century, stretching to the properties of the Byzantine Empire (including most of Southeast Europe) and the Middle East, including 
any other law, had gone through a very challenging path of its development. This legislation, which in fact was the Sharia law, looking in a general context, contained relatively numerous norms on personality rights, family and inheritance law, marital and property rights, and obligation law. Consequently, "Islamic Law was based on its four fundamental sources: The Qur'an, the Sunnah (the principles of Muhammad), the Icma (Muslim scholars) and Klyas (analogy)". ${ }^{41}$ The Qur'an and the Sunnah were primary sources of the Sharia law, while secondary sources were Icma and Klyas. ${ }^{42}$ It should be emphasized that the rules of Islamic law apply only to Islamic citizens. For other citizens, these rules were not applied $^{43}$.

The Islamic Law (Sharia law) was called Fiqh. ${ }^{44}$ This was a law with religious premises, which at the same time regulated other social relationships in the Islamic community that were not merely of a religious character. Sharia law addresses the whole human lifestyle. It deals with human behavior as such, which implies all forms of spiritual, moral, and bodily action. ${ }^{45}$ Generally speaking, the Sharia law has a

Egypt. Though the first beginnings of the collapse of the Islamic state were marked in 1590, its collapse appears to have occurred in the decades of beats in the year 1600. For this, see: Inan Kenan, The Making of Kanun Laë in the Ottoman Empire, 1300-1600, Published by Edizioni Plus - Pisa University Press, fq. 66. Available at: http://www.cliohworld.net/onlread/5/07.pdf.

41 Bozkur, Gülnihal, 'Review of the ottoman legal system', (1994) 71(2) Der Islam: Journal of The History and Culture of Middle East, p.115, Available

at: http://dergiler.ankara.edu.tr/dergiler/19/835/1056 3.pdf; see also: Javaid, Rehman and Aibek, Ahmedov, Edited by Shaheen Mansoor - Sources of Islamic Law, The higher education academy, 2011, p. 18, 21, 27, Available at: http://pgil.pk/wpcontent/uploads/2014/04/Sources-of-IslamicLaw.pdf; see laso: Andrea, Büchler, Introduction to Islamic and Middle Eastern Law FS16, Zurich, 2016, p. 16, Available at: special focus on the right of obligations, with particular emphasis on the contracts, and within them was accorded the right space to the all types of defect in consent, namely to the threats and duress, and also to the fraud and mistake. This right similar to other early laws had accepted the rule under which the contract could only be related to the will of the contractual party's.

Consequently, according to the rules of this law without the consent of the parties, there could be no contract. The all sources used, prove that in the first stages of development of this law most of the contracts were related orally, whereas later contracts were mainly related to writing form. In order to consider the validity of a contract, only the agreement (dealing) between the contractual party's would be sufficient, but the essential elements that determinate the validity of the contract were the ability of the contracting parties and their will should not be affected by defects in consent such as mistake, duress, fraud or misrepresentation. If the will was accompanied by such a defect of consent, the contract could be avoidable. ${ }^{46}$

As it turns out, Islamic law, among other things, had addressed the issue of wills

https://www.rwi.uzh.ch/dam/jcr:00000000-0bb90e00-ffff-

ffffb2e82aa8/HistoricalOverviewandSources.pdf; see also: Lily Zakiyah Munir, General Introduction to Islamic Law. Kamali, (1991) 18, p. 7, Available at: http://www.lfip.org/laws718/docs/lilypdf/Introduction_to_Islamic_Law.pdf

42 Abu Umar, Faruq Ahmad, Law and Practice Of Modern Islamic Finance in Australia, Sydney 2007, p. 41

43 Halil Cin, Ahmet Akgündüz, Türk Hukuk Tarihi (Turkish History of Law), I, Konya, 1990, p. 77

44 The science that deals with the Sharia law study are called "fiqh", while the good jurist of sharia law was called "muftis".

45 Ismadji, above n 1, p. 212

46 Ala'eddin, Kharofa, The Loaun Contract in Islamic Shari'ah and Man-Made Law: A Comparative Study, (Kuala Lumpur, Leeds Publications, 2002) p. 15 
that could be expressed in the cases of the conclusion of the contracts. Thus, besides duress and mistake, also considered fraud as a defect in consent. In Islamic law, a number of words were used to mean fraud, such as: hud'a or hadi'a, mekr, keyd, tedlis, tağrîr, gaşş or glşş. ${ }^{47}$ Solutions addressing the fraud involved in Islamic law did not make any difference to the solutions that this phenomenon had made to other ancient laws. In this symmetry, this right provided that "If approval was granted under the influence of fraud, the contract existed, but flawed"48. Hence, within the scope of this right according to fraud, the intention was to create a rephrasing on the other side with an untrue view to concluding a contract that was unfavorable to that party. According to this definition, the contract was concluded under the fraud effect, when the other party acted in a way other than what he submitted. For example, dyeing clothes for the purpose of introducing them as new was considered fraud.

The Islamic law divided fraud into verbal fraud "Fiyat", and fraud by action named "Vastf". This law even recognized the deception made with active and passive actions (mere silent). Also, this law regulated the fraud done by a third person, and always the deceived party may rescind the contract. ${ }^{49}$ This means that the fraud-related contracts were considered avoidable contracts, but that annulment depended on the party's initiative. The right to rescind the contract related to fraud had the deceived party "hiyar $-i$ tağrir". ${ }^{50}$ The same opinion was given by

47 Köse Saffet, İslam Hukukunda Kanuna Karșı Hile, Birlesik, İstanbul, 1996, p. 94

48 Ahmed, Akgündüz, Íslam ve Osmanl Hukuku Külliyatı, 2. Cilt - Özel Hukuk II, İstanul, 2012, p. 232

49 Mustafa, Ahmed Ez-Zerka and Servet, Armağan, Çă̆daş Yaklaşımla İslam Hukuku, (1993) Cilt 1, İstanbul, p. 282-286
Imam Malik when he cited that "the right to avoid the contract was given to the deceived party". ${ }^{51}$ Also as conditions for annulment of the contract in Islamic law, were known; wiliness, false statements, silence or concealment of facts, and fraud done by a third party. In such cases, the deceived party could avoid the contract within one year from the day they know about the fraud. ${ }^{52}$ Thus, the cost of the object of the contract constitutes an important element in the contracts based on good faith. So, if one of the parties enters into such a contractual relationship (e.g. the buyer) who has neither knowledge of the product nor does have experience in business, and on the other hand (the seller) who is deemed to have done fraudulent conduct, in case he is making false statements or hiding facts that result in the conclusion of the contract, ${ }^{53}$ and the contract had a high financial cost, in this case to the deceived party was recognized the right for avoiding the contract.

During the Ottoman Empire, the broader scope was from the Islamic law, namely Sharia's law. Ottoman law had three court systems, one for Muslims, one for nonMuslims, and another trade court. The Islamic law, as noted above, applied only to the Islamic community, and not to the one who was not a Muslim. Because of the influence of Europe within the Ottoman Empire, it was constantly proclaimed that there would be changes in the justice system of this Empire, hence within Islamic law itself. The reforms were based on the French model, in 1877 they were introduced through

50 Ibid

51 Hayredin, Karaman, İslam Hukuku, Ana Hatlarıla 3, (2017) Cilt, 19. Istanbul, Bask1, ensr, p.79

52 Ahmed, Akgündüz, İslam ve Osmanll Hukuku Külliyatı, 2. Cilt - Özel Hukuk II, İstanul, 2012, p. 233

53 Ibid, p. 80 
the Civil Code called "Mecelle". 54"Mecelle" was a Civil Code that was implemented during the last period of the Empire, known by his full name "Mecelle- $i$ Ahkâm-ı Adliyye".55 Mecelle-i Ahkâm-ı Adliyye, consisted of the introduction, 16 books, and 1851 articles.157 These books addressed; büyü (sales), icârât (leases), bail, pledge, trade, claims, etc. ${ }^{56}$ These books addressed: büyü (sales), icârât (leases), bail, pledge, trade, claims, etc. 57 "Mecelle" was applicable in Turkey until 1926 when it was replaced by the Turkish Civil Code, while in Albania until 1928. In some other countries such as Cyprus and Palestine, this Code was applicable until the 60s and 70s, and in Yemen, it was applied until 1992. ${ }^{58}$

In Mecelle the phrase "tağrir", had the definition of fraud. The party that was deceived was entitled to avoid the contract "hıyar-l tağrir", and if it had any damage, it could seek compensation for the damage from the other party. According to "Mecelle", the right to annul the contract due to fraud could be used within one year from the day it was learned about fraud, and under any circumstances, the statutory limitation was three years ${ }^{59}$.

Finally, it can be concluded that in Turkey until 1926, among others, the Sharia law and the Civil Code called "Mecelle" were applied, while the issuance of the Civil Code of 1926 abolished other laws applied until that time.

Islamic law is also considered quite advanced in dealing with fraud. Islamic law

54 Osman Kaşıkçı, İslâm ve Osmanlı Hukukunda Mecelle, Osmanlı Araştırmaları Vakfı Yayınları, İstanbul, OSAV, 1997, p.61-71

55 Şimşirgil, Buğra, Ekinci, Ahmed Cevdet Paşa ve Mecelle, İstanbul, KTB, yayiniari, 2009, p. 49, Available at: http://www.muharrembalci.com/kitaplika/32.pdf

56 Mustafa Yildirim, Mecelle'nin Küllî Kâideleri, İzmir, 1st edition, İzmir Theology Faculty Foundation Publications, 2001, p.15 is also considered quite advanced in dealing with fraud. In particular, the detailed treatment of contractual relations in Mecelle is considered a major advantage, which greatly influenced the followed codes and laws issued in those countries where Sheria has been applied.

\section{Fraud in the Old Turkish Law}

The data's on the ancient laws of Turkish obligations are based on the legal documents inherited by the Uyghur's. During the time of the Uyghur's, there was a lifetime of more trade action, as well as numerous contracts were prepared in the framework of certain rules. ${ }^{60}$ The history of Turkey's development was very long that included a long period of time, as well as various systems within it. This reality, also based on the nature of this paper, is hard to handle the fraudulent occurrence into obligation relationships, in a detailed and general context. Based on this fact, in the continuation of this doctoral dissertation, this unlawful phenomenon will be elaborated in the way it was addressed in the framework of the civil legislation which came into force in 1926, and was applicable until 2012, when the new Code of Obligations was issued.

Turkey's Civil Code and Turkey's Obligation Code of 1926 entered into force 90 years ago, which changed social life in many important aspects. The approval of these laws was a very courageous step from Ataturk, and Mahmut Esat Bozkurt who was the Minister of Justice at that time, a step that

57 Ali Himmet, Berki, Açıklamalı Mecelle (Mecelle-i Ahkâm-ı Adliyye), Hikmet Yayınları, İstanbul 1979 , p. 103

58 Şimşirgil, above n 55, p. 59

59 Ahmet, Akgündüz, Türk Hukuk Tarihi, 2. Cilt, Özel Hukuk, Istanbul, 1996, p. 196-197

60 Aysun Dursun, Türk Halk Hukuku, Istanbul, 2016, p. 154; see also: Halil, Cin, Gül Akyılmaz, Türk Hukuk Tarihi, 9. Bask1, Konya, 2017, p. 49 
made a big turnaround on Turkey's journey. Many scholars considered this an important step not only in the field of justice but also in the social sphere, such as the well-known Professor Kudret Ayiter said: "We have not advanced only 40 years since 1926, but maybe 2000 years" (quoted in 1966). ${ }^{61}$

The Code of Obligations of 1926,163 in addition to other issues related to obligations (principal aspects and types of obligations), central and important place was devoted to contracts. Concerning the contracts, this Code paid special attention to the defects in consent, which is addressed in the provisions of Arts. 23 to 31 thereof. In conformity with the relevant legal remedies as defects in consent under this code were considered: mistake, fraud, and duress.

Turkey's Obligation Code of 1926 regulates the issue of fraud in contracts by Art. 28 and within the two separate paragraphs. "When a party concludes a contract under the effects of another party's fraud, it is not related to that contract even if its mistake is not essential" (first (1) par. of Art. 28). In accordance with this legal deception, provision existed in each case when one party caused or held back the other party with the intention of thereby affecting it to enter into a contract that would be detrimental to it. Fraud is considered to exist not only in cases where it was related to the essential elements of the contract but also in cases of non-essential elements. Such a solution is considered important for the fact that through it, the Turkish lawmaker

61 Ayiter, Kudret, Türk Medeni Kanununun 40 Inci Yili, 4 Ekim 1966, Ankara Üniversitesi Hukuk Fakültesi Dergisi, 1(1), p. 152. Available at: http://dergiler.ankara.edu.tr/detail.phpid=38\&sayi id $=213$

62 Lütfü Dalamanli, Içtihatlı ve örnekli Tatbikatta Satış Vaadleri Ölünceye Kadar Bakma ve Miras Taksim Sözleşmeleri, (1980) Büyükçekmece, , p. 22-23 defended the deceived party in all the dimensions and types of fraud seen in the context of obligational relationships. Such a legal solution accords the right of the deceived party to demand annulment of the contract within one (1) year. ${ }^{62}$

Meanwhile, according to second (2) par. of Art. 28 of this Code of Obligations, it is stated that "a party concluding a contract under the effects of fraud from a third party is not bound by the contract if the other party knew or could have known about the fraud".

According to this legal provision, fraud also existed when it was done by a third person. This means that the deceived party was not related to the contradiction nor when the fraud came from a third person. However, in order for this situation to emerge, it was required that the other contracting party knew or ought to know about fraud. ${ }^{63}$ Based on this, the deceived party was entitled not to fulfill the obligations arising from it, from a contract whose affiliation had been made under the effects of fraud through the third parties, if the other party knew or should have known about the fraud.

According to the Turkish Obligation Code of 1926, the fraud-related contract was considered a rescindable contract. This means that that "ex - lege" was not considered invalid, but could be declared such if it was declared by the deceived party. Due to the defects in consent, the contract was considered avoidable or like it had not been concluded at all. ${ }^{64}$ This Code, in addition to the possibility of annulment of the

63 The expression "should know" about the fraud, is referring to cases where a contracting party, at the time of entering into a contract did not know about fraud, but looking to his general knowledge and experience he should have known about the existence of this unlawful phenomenon.

64 Akif, Aydın, Türk Hukuk Tarihi, 7 baskı, Instanbul, 2009, p. 378 
contract, concluded under the effects of fraud on the deceived party, also knew the right to compensation for the damages suffered by such a contract.

It is worth mentioning the fact that Turkey's Obligation Code of 1926 represented an advanced code of the time. This finding results from the fact that its solutions to the fraud phenomenon are solutions that almost similarly contained other relevant advanced laws of that period of time. Also, we can freely say that the old Turkish law is quite influenced by Islamic law. Therefore, even the treatment of fraud as an unlawful act has been affected by Islamic law.

\section{A short historical review of fraud in Kosovo}

Given the fact that Kosovo has long been governed by many foreign regimes and powers, it is natural, that in its territory different legislation was applied. Looking at this, during the time of administration from the Ottoman Empire in Kosovo, alongside the customary Albanian law, which was applied in great measure, ${ }^{65}$ also acted the law of Sharia, Turkish Canons, and the Turkish Civil Code of 1926. Thus, in Kosovo at that time there was a so-called juridical dualism because, in addition to the application of the right of Sharia and Turkish Civil and Procedural Law, the Albanian Customary Law has also been applied within it the civil law (including the right to obligations).

Following the occupation of the Kingdom of Slovenes-Croats-Serbs (1918), civil legislation began to be applied in Kosovo, which had the blessing of this Kingdom. In this regard, it should be emphasized that in relation to the Albanian

65 Durham, Edith, Brenga e Ballkanit, Naum Veqilharxi, Tiranë, 1998, p. 221-222 community this legislation was abused greatly. ${ }^{66}$ This was due to the fact that with the aim of populating Kosovo with Slav populations, numerous documents were issued through this, which the population was transferring the property rights of the land, housing, and everything else, all this to detriment of the majority Albanian population. These documents were also backed up by various false and fraudulent contracts, but which resulted in the legalization of those properties because the regime of this kingdom was behind them.

In Post - World War II, Kosovo, as it was under the jurisdiction of Socialist Yugoslavia, the civil and procedural legislation which in that country was applied. In this aspect, it is worth mentioning, in particular, the Law on Obligational Relationships of 1978, which in its format had advanced relatively much in terms of solving many issues and dilemmas involving void contracts, including those related to fraud.

After the end of the war in 1999, NATO's intervention and deployment of the United Nations Interim Administration Mission in Kosovo (UNMIK) in order to fill the legal vacuum, by UNMIK Regulation No. 1999/1 and no. 1999/24 as legislation applicable in Kosovo was proclaimed the legislation of 28 March 1989, which it was in force in Kosovo. Thus, with regard to the right to obligations, in Kosovo was applicable the Law on Obligational Relationships issued in 1978. Thereafter, Kosovo in 2012, for the first time in its history has its own Law on Obligational Relationships, which ultimately dissociated the legal continuity of the previous legislation in the law of obligation (LORK,

66 Castellan, Georges, Histori e Ballkanit, Tiranë, 1997 , p. 257, 258 
2012, Law No. 04/L-077). In the context of fraud that is the subject of this dissertation, will be elaborated hereinafter.

\section{a. Fraud according to customary Albanian Law}

The Albanian customary law, summarized in the Code of Lekë Dukagjini, the Code of Skanderbeg, and the other canons from different Albanian territories (the Code of Labëria, Code of Dibra, etc.) contains, among other things, a system of civil and procedural legal norms regulating fundamentally matters of civil law affairs, including those of obligational relationships character.

Consequently, within this doctoral dissertation, modest attempts are made to explain the issue of fraud in obligational relationships in the way that it has dealt with this law, ${ }^{67}$ especially the Code of Lekë Dukagjini, which was the only code applied in the territory of Kosovo at that time (Canon of Lekë Dukagjini, 1999).

This explanation is of interest to the fact that not a few norms of customary law, along with positive law, have long been preserved in people's consciousness and they have acted in parallel with it. Dualism or legal pluralism is a historical reality not only for Kosovo but also for many other countries in the world. ${ }^{68}$

67 The customary Albanian law was spread over a considerable number of canons. Such were, the Canon of Lekë Dukagjini (which was mainly applied in Kosovo), the Canon of Skanderbeg (see: the publication Shkodra, 1993), the Canon of Laberia, the Canon of Dibra, the Canon of Puka, etc.

68 Hajdari, Azem, Juvenile criminality in Kosovo, Sarbrucken, Lambert Academic Publishing, 2016, p. 16

69 Vjeta V., Dhetuer, Hylli i dritës Nr. 12, Shkodër, 1924, p. 549

70 Elkezi Ismet, $E$ drejta zakonore penale $e$ shqiptarëve, Tiranë, Toena, 1983, p. 41
The Lekë Dukagjini Canon, contains 12 books, 24 chapters, and 1263 Articles. ${ }^{69}$ In the Code of Lekë Dukagjini, civil legal norms, especially those referring to the right of obligations, were scarce. They were not properly sorted and there were some repetitions. ${ }^{70}$ Within the framework of the obligations-related norms, some issues directly related to the contracts, which were of several types and were of interest for the improvement of the lifestyle of the citizens of Kosovo, were regulated, with a particular approach on avoidable contracts. ${ }^{71}$

According to the Canon of Lekë Dukagjini and other Albanian codes, contracting subjects were natural persons who possessed legal capacity and the ability to act. ${ }^{72}$ In this code related subjects are presented as follow:

First, the contract was concluded between the head of the family who represented the house as a creditor or a debtor $^{73}$. With the blessing of the head of household, as a subject of the contract could be one another family member, but it should always be a man.

Second, when the contract was linked between the brothers or between brotherhood and a particular person, as a rule in the name of brotherhood acted the one who represented him, who was authorized to carry out civil legal actions and not whoever, but

71 Elezi, Ismet, Omari Luan etj., Historia e shtetit dhe e së drejtës në Shqipëri, Pjesa II, Tiranë, 1997, p. 42

72 Relationships between citizens could have the right content and obligations of property of wealth and juro, but the majority were of a wealth of character.

73 See, Article 20 of the LDC; To manage the house belongs to the oldest person who lives at the home, usually it may be the first brother. The fourth paragraph of this canon grants the owner a right to buy, sell or change land (fields, work tools, houses, etc.), animals, and other things. According to these kinds of cases, we could refer also to the Articles 25, 62 and 105, of this Canon. 
only the one who was in charge of managing the partnership economy of the brotherhood.

Third, when one of the contraction party's was collective in the contract, for instance, the village as a subject in the contract was represented by the headman of the village (the eldest man in the village, for example, when signing a lease contract $)^{74}$.

Fourth, as subjects of obligations relationships (as a general rule) were men, while women had very limited rights, in many aspects of their life, including them of obligations relationships. Exceptions to this general rule made some contracts, such as lending the household items (mostly food) such as flour, milk, cheese, etc., where the householder could also be a woman, who managed the housework. ${ }^{75}$

Fifth, the contracts were concluded orally, based on the moral principle of the pledge of honor, trust, and good faith. Naturally, this did not exclude cases of the conclusion of written contracts when it comes to the sale of immovable properties, houses, land, etc. Looking at this aspect, it was essential to have a contract based on the free will of the parties.

The Lekë Dukagjini Canon, regarding the execution of the obligations, demanded that this should be done with precision. As a rule, the contract was executed voluntarily by the parties. When there was disagreement, the matter was adjourned and resolved by elders, whose decision was compulsory for the parties to enforce.

Lekë Dukagjini's Canon recognized these ways of extinguishing the obligations: by paying the debt, by committing the debt,

74 Elezi, Ismet, E drejta zakonore e Labërisë në planin krahasues, Tiranë, 1994, p. 120

75 Elezi, Ismet, Kanuni i Labërisë, Botiment Toena, Tiranë, 2006, p. 19

76 Elders had the meaning of the court. It consisted of the oldest and knowledgeable peoples. The elders (oldest men) in the composition were attributed or by forgiving. In the contractual obligations relationship of this Code, the limitation periods were not known. Debt had to be redeemed at any time. When the debtor passed away the debt was passed to the heirs who were forced to pay for it.

Canon of Lekë Dukagjini's had also addressed the issue of a defect in consent in conclusions of contracts. He considered invalid any contract related to fraud, duress, and threats. Fraud is considered to exist when, for example, selling animals to the buyer, also work tools and weapons, etc., with some defect for which he did not tell about when the contract was concluded. Though the canonical solutions do not expressly emphasize, it was a rule that in these cases the defects were of essential character, which seriously deceived the will of the contracting parties, because the purchased item was largely dysfunctional, of other different quality or origin than what the parties had agreed to, etc. This usually came to light in cases where, for example, a weapon was purchased that had been masked by defects that made it even ineffective (cracked and shortened barrel, etc.).

The contract concluded under the effect of fraud, could be made void from the group of elder people. ${ }^{76}$ They could decide that the contract could be annulled in whole or in particular. Obviously, the level of avoidable of the concluded contract based on fraudulent conduct depended on the degree of deficiency that contained the subject of the contract, the circumstances of the fraud, the interest of the parties, and so on.

from both sides. The number of elders members to settle the cases between the parties, depended and it was different from case to case, but usually, there were three or more elders. Elders decided unanimously or by a simple majority vote. Individual elders were able to engage, in solving certain case issues. 
According to the solutions provided in the Canon of Lekë Dukagjini, the fraudulent party that had put the party to conclude the contract under the effect of fraud was under the obligation to compensate for the caused damage. Compensation for the damage was done to the benefit of the deceived party. The amount of damage compensation in many cases was disproportionate (they paid a higher price) compared with the damage that the contractor had suffered and this was due to the misuse of the trust. Looking at this, the Art. 740 of this Canon, clarifies the fact of the obligation to compensate the damage of any party who in any fraudulent contract had suffered any damage. The Canon of Lek Dukagjini does not recognize the penalty as a punishment for the person who had caused the damage to the other contracting party, including situations when it was done fraudulently. Looking at this aspect, the Canon says "the damage has a price, but not penalty" "77 and "the damage has a price, but no rifle" ${ }^{, 78}$. This means, that for fraud in concluding contracts, the Canon of Lekë Dukagjini did not foresee the punishment of the deceiver by penalty or murder.

\section{b. Fraud under the Law on Obligations on the Former Yugoslavia}

After World War II, the Yugoslav military administration on 8 February 1945 was set up, which aimed to forcefully stamp out any attempts by the Albanian population to achieve national aspirations for democracy ${ }^{79}$. The occupation of Kosovo by the Yugoslavian army, besides being associated with terrorist acts, military operations, and massacres, was also followed

77 See: Article 735 of the LDC.

78 See: Article 739 of the LDC.

79 Encyclopedic overview of Kosovo, 1999, p. 118 by the imposition of its legislation. ${ }^{80}$ Initially, the laws of the Kingdom of Serbs - Croats and Slovenes were imposed, and then the new laws were gradually being created in the formal republic of Yugoslavia. This approach made no exception to civil law, including that of obligational relationships.

Since the dimensions of the frameworks under this subject of doctoral dissertation have another aim, my focus is on the reflection of the structure, and especially the way of regulating the issue of defect in consent to the contract, with a special focus on fraud, regulated by the Law on Obligations of the Former Yugoslavia of 1978 (Article 58). According to this Law, subject of a contract may be a natural person, who's having legal capacity and ability to act. The contract was considered to be concluded when the contracting parties had agreed on the essential elements of the contract.

The Law on Obligations of the Former Yugoslavia addressed the issue of defects in consent between Arts. 53 to 59. This law as a defect in consent includes duress (Art. 53), mistake (Art. 54), mistake in the motive for a gratuitous contracts (Art. 55), misunderstanding (Art. 56), indirect declaration (Art. 57), fraud (Art. 58) and void contract (Art. 59). A simple scientific analysis that can be made of these articles reveals the fact that this Law, in essence, recognizes three types of defects in consent: duress, mistake (though treated separately as mistake and mistake in the motive of the gratuitous contracts, controversy and indirect declaration) and fraud (even though treated purely as a fraud and as a void contract).

Under this law, fraud existed when certain actions were taken by one of the contractual party's, or when concealing the

80 Braha, Shefqet, Gjenocidi serbomadh dhe qëndresa shqiptare, (1944 - 1990), Gjakovë, 1991, p. 498 
facts for the purpose of causing or holding the other contracting party to mislead. In essence, here mistakes are over the decisive facts that causes the validity of the contract. But fraud could also be the consequence of certain conducts or inaction, or the interference of the third persons. ${ }^{81}$

The solutions addressed in the Law on Obligations of the former Yugoslavia, the fraudulent conduct was considered as third kind of defect in consent in the contractual relationships. As noted above, fraud is addressed precisely in Art. 58 of this Law, but somehow in a more specific sense, was extended to Art. 59.

In Art. 58 of the Law on Obligations of the former Yugoslavia, fraud was addressed within four separate paragraphs: In the first paragraph, the Yugoslav lawmaker had defined the meaning of fraud and the consequences of entering into a contract under it. According to this legal provision, fraud had existed if one party caused the other party to mislead or mistaken it in order to postpone the conclusion of a contract which was unfavorable to it. Fraud was a cause to rescind the contract. Consequently, the fraud - related contracts was considered an avoidable contract. Fraud appears to have been the basic element for the Yugoslav legislature to grant the deceived party the right to avoid such a contract.

For the existence of fraud conforming to the legal solution defined in this paragraph, two conditions should be fulfilled: the first one is referred to the purpose. The purpose existed when it one of the contracting party willfully mislead the other party to conclude the contract under the effects of fraud. But the second condition that was closely related to the first one, it was the one expressed in the undertaking of various actions through which a misleading the relevant facts of the contract. "To have fraud as a defect in consent, there was a need for causal relationship between fraud and declaration of will. Fraud always assumes "mala fide" on the side of the party that uses it". ${ }^{82}$ The other (conscientious) party could request the annulment of the contract even when the fraud was not essential.

The fraud could be made with active and passive conductions. But essential was considered to be only the fraud that had a strong impact on the other party without which the contract would not have been concluded.

The second (2) par. of this article established another right of the deceived party, to compensation for damage. The party who had concluded the contract and was being under effect of fraud, had the right to claim compensation for the damage caused. The realization of this right was related to whether the contract was declared avoid or not. Therefore, when the contract declares void, the deceived party may ask for compensate for the damage suffered from the fraudulent party.

The third (3) par. addressed the issue of fraud when it came from a third person. The solution addressed in this legal provision provided that when fraud was committed by a third person, it affected the contract itself. This means that such contract may be rescind from the deceived party. However, in order
81 Perović Slobodan, Stojanović Dragolub, Komentar Zakona o Obligacionim Odnosa, Kragujevac, Kulturni centar, 1980, p. 246: see also: Hajdari, Egzonis, Erlüle, Fulya, Elements, types and consecuences of fraud according to Obligation Law - A comparative approach between legislation in Turkey and Kosovo, International Comparative Jurisprudence, Vol. 4 / Iss. 2, 2018, p. 164, Available at: http://dx.doi.org/10.13165/j.icj.2018.12.007

82 Ibid. Perović Slobodan, p. 247 
for this to happen, it was required that the other contracting party at the time of the conclusion of the contract could be aware or ought to have known about the fraud.

The fourth (4) par., addresses the issue of annulment and compensation of damage in cases of gratuitous contracts under the effects of fraud from a third party. The law expressly stated the fact that even gratuitous contracts could be annulment, irrespective of whether the contracting party knew or ought to have known about the fraud at the time of the conclusion of the contract. The compensation rules were identical as in cases where fraud was made by the contracting party, or when it made by a third person; The importance was the causal relationship between the the contract and the fraudulent conduct.

As noted above, the fraud-related contract could be annulled. It could be annulled at the request of a deceived party when it was filed within the statutory deadline required (Art. 111), for the reasons under which the private interest was violated. The contract should have had legal effects, although their avoidance was uncertain, as this depended on the will of certain persons, for which reason, in the legal theory, they were called contingent contracts. ${ }^{83}$ Despite this fact, at the request of the deceived party to annul the contract, the court was obliged to annul it, which means that its decision had constitutional effects. ${ }^{84}$

The Law on Obligations of the Former Yugoslavia represents a very advanced law at that time, including the period of existence of the former Yugoslavia and beyond it. This finding is based on the fact that almost all the states that emerged from the former Yugoslavia have had a basic pattern of issuing their laws on the obligational

83 Radišić Jakov, Obligaciono pravo, Opšti deo, S.A.M Konsalting Center BGD, Beograd, 2004, p. 175 relationship. This finding also refers to Kosovo as well. According to this, we can conclude that this law has been an impact on many subsequent laws, especially for the state that has emerged from the former Yugoslavia, including Kosovo. Moreover, the Law on Obligation Relationships of Kosovo stipulated fraud in the same way as this law did.

\section{CONCLUSIONS}

The practical treatment of fraud is likely to have occurred since the genesis of the appearance of this phenomenon, for its more appropriate treatment can be talked about after the implementation of the first legal systems, which in their focus had contractual relationships. Consequently, the written sources of the phenomenon of fraud are initially manifested in Babylonian law, to continue with the old Greek law, Roman law, Islamic law and the customary laws. According to Hammurabi Code it is not mentioned the phenomenon of fraud in the contractual relationships of the parties at all. However, this does not mean that this legal act did not at all address the issue of this phenomenon. Also, the Ancient Greek law has considered the issue of defects in consent in contractual relationships relatively late. Under this law, the fraudulent party could be prosecuted and forced to compensate the damage they caused; same was under Roman law as well. The serious treatment of the defects in consent in contractual relationships under Roman law starts with the recognition of bona fide contracts.

Moreover, Islamic law is considered quite advanced in dealing with fraud, especially in elaborating its consequences. On the other hand, the Canon of Lekë

84 Nikolić Ďorđe, Obligaciano pravo, Organizacija za pravnu edukaciju i kulturu prava "Projuris", Beograd, 2006, p. 57 
Dukagjini, has also addressed the issue of the defect in consent in contractual relationships. This canon considered avoidable any contract related to fraud, duress, and mistake. But under this canon, if the contract was concluded under the effect of fraud, could be avoid from a group of elder peoples. Plus, the fraudulent party may be presucated, same as in and to compensate the dameges that have been caused. Furthermore, the Law of Obligations of the Former Yugoslavia of 1987, gave the deceived party the right to avoid the contract relating to fraud and also could be asking for the compensation. This law was advanced from the previous laws but was also the main source that the Law on Obligational Relationships of Kosovo has based on.

\section{REFERENCES}

\section{Books}

Abu Umar, Faruq Ahmad, Law and Practice Of Modern Islamic Finance in Australia, Sydney 2007.

Ahmed, Akgündüz, İslam ve Osmanl Hukuku Külliyatı, 2. Cilt - Özel Hukuk II, İstanul, 2012.

Ahmet, Akgündüz, Türk Hukuk Tarihi, 2.

Cilt, Özel Hukuk, Istanbul, 1996.

Akademia e Shkencave e Shqipërisë, $E$ vërteta mbi Kosovën dhe shqiptarët në Jugosllavi, Tiranë, Instituti i Historisë, 1990.

Akif, Aydın, Türk Hukuk Tarihi, 7 baskı, Instanbul, 2009.

Akıncı, Şahin, Roma Hukuku Dersleri, Konya, 2003.

Ala'eddin, Kharofa, The Loaun Contract in Islamic Shari'ah and Man-Made Law: A Comparative Study, Kuala Lumpur, Leeds Publications, 2002.
Ali Himmet, Berki, Açıklamalı Mecelle (Mecelle-i Ahkâm-ı Adliyye), Hikmet Yayınları, İstanbul 1979.

Aysun Dursun, Türk Halk Hukuku, Istanbul, 2016.

Bilalli Asllan, Bahtir Bedri, E drejta romake, Prishtinë, Prishtine University, 2015

Borkowski Andrew, Plessis du Paul, E Drejta romake (përkthim shqip), Tiranë, Univerziteti i Prishtines, 2009.

Braha, Shefqet, Gjenocidi serbomadh dhe qëndresa shqiptare, (1944 - 1990), Gjakovë, 1991.

Çaglar, Özel, Turkish code of obligation, 3 Baski, Istamboll, 1991.

Castellan, Georges, Histori e Ballkanit, Tiranë, 1997.

Coşkun Üçok, Ahmet Mumcu, Türk Hukuk Tarihi (Turkish History of Law), Ankara 1976.

Durham, Edith, Brenga e Ballkanit, Naum Veqilharxi, Tiranë, 1998.

Elezi, Ismet, E drejta zakonore e Labërisë në planin krahasues, Tiranë, 1994.

Elezi, Ismet, Kanuni i Labërisë, Botiment Toena, Tiranë, 2006.

Elezi, Ismet, Omari Luan etj., Historia $e$ shtetit dhe e së drejtës në Shqipëri, Pjesa II, Tiranë, 1997.

Elkezi Ismet, $E$ drejta zakonore penale $e$ shqiptarëve, Tiranë, Toena, 1983.

George, Grote, A History of Ancient Greece Solon's Early Greek Legislation, Jhon P. Jewet \& Company, Boston, 1851, Available at:: http://historyworld.org/solon.htm

Halil Cin, Ahmet Akgündüz, Türk Hukuk Tarihi (Turkish History of Law), I, Konya, 1990.

Halil, Cin, Gül Akyılmaz, Türk Hukuk

Tarihi, 9. Baskı, Konya, 2017.

Halûk N. Nomer, Borçlar Hukuku Dersleri

Genel Hükümler, Istanbul, Beta, 2020. 
Hayredin, Karaman, İslam Hukuku, Ana Hatlarlyla, 3. Cilt, 19. Istanbul, Bask1, ensr, 2017.

Hajdari, Azem, Juvenile criminality in Kosovo, Sarbrucken, Lambert Academic Publishing, 2016.

İnan Kenan, The Making of Kanun Laë in the Ottoman Empire, 1300-1600, Published by Edizioni Plus - Pisa University Press, 2008, Available at: http://www.cliohworld.net/onlread/5/0 7.pdf.

Ismajli, Hilmi and Sejdiu, Fatmir, Historia e shtetit dhe së drejtës I, Prishtinë, Universiteti i Prishtines, 2005.

Janjić-Komar M, Korać R, Ponjavić Z. Porodično pravo. Dečje novine; 1994

Javaid, Rehman and Aibek, Ahmedov, Edited by Shaheen Mansoor - Sources of Islamic Law, The higher education academy, 2011. Available at: http://pgil.pk/wpcontent/uploads/2014/04/Sources-ofIslamic-Law.pdf;

Kanuni i Lekë Dukagjinit, Kuveni, Tiranë, 2001

Köse Saffet, İslam Hukukunda Kanuna Karşı Hile, Birlesik, İstanbul, 1996

Lütfü Dalamanli, İçtihatll ve örnekli Tatbikatta Satış Vaadleri Ölünceye Kadar Bakma ve Miras Taksim Sözleşmeleri, Büyükçekmece, 1980

Mandro Arta, E drejta Romake, Tiranë, 2004. Mustafa, Ahmed Ez-Zerka and Servet, Armağan, Çă̆daş Yaklaşımla Íslam Hukuku, Cilt 1, İstanbul, 1993.

Mustafa Yildirim, Mecelle'nin Küllî

Kâideleri, İzmir Theology Faculty

Foundation Publications; 1st edition, İzmir 2001.

Ngjela Spartak, E drejta romake, Tiranë, UET, 2000

Nikolić Ďorđe, Obligaciano pravo, Organizacija za pravnu edukaciju i kulturu prava "Projuris", Beograd, 2006.

Osman Kaşıkçı, İslâm ve Osmanlı Hukukunda Mecelle, Osmanlı Araştırmaları Vakfı Yayınları, İstanbul, OSAV, 1997.

Perović Slobodan, Stojanović Dragolub, Komentar Zakona o Obligacionim Odnosa, Kragujevac, Kulturni centar, 1980.

Radišić Jakov, Obligaciono pravo, Opšti deo, S.A.M Konsalting Center BGD, Beograd, 2004.

Puhan Ivo, E drejta romake (translatied in albanian), Prishtinë, 1980

Selmani, Bashkim and Rexhepi, Bekim, $E$ drejta romake, f. 656-661, Ferizaj, 2014.

Şimşirgil, Buğra, Ekinci, Ahmed Cevdet Paşa ve Mecelle, İstanbul, $\mathrm{KTB}$, yayiniari, 2009. Available at: http://www.muharrembalci.com/kitapl ika/32.pdf

Vjeta V., Dhetuer, Hylli $i$ dritës Nr. 12, Shkodër, 1924.

Umur Ziya, Roma hukuku ders notlari, 3 basim, Istanbul, Beta Yayınevi, 2010.

\section{Journals and Reports}

Ayiter, Kudret, Türk Medeni Kanununun 40 Inci Yili, 4 Ekim 1966, Ankara Üniversitesi Hukuk Fakültesi Dergisi, Volume 1, Issue 1, Available at: $<$ http://dergiler.ankara.edu.tr/detail.ph pid=38\&sayi_id=213>

Badamchi, Hossein, Fraud and Forgery in Old Babylonian Law, Wiesbaden, Journal For Ancient Near Eastern an Biblical Law, (2016) 22. Available at: https://www.academia.edu/33033088/ Fraud_and_Forgery_in_Old_Babyloni an_Law_in_Zeitschrift_für_Altorienta lische_und_Biblische_Rechtsgeschich te 
Barbara, Biscotti, Debtor's Fraud In Roman

Law An Opportunity For Some

Briefremarks On The Concept Of

Fraud, Fundamina, (2011) 17(2),

Available at:

https://www.academia.edu/4179151/D

EBTOR_S_FRAUD_IN_ROMAN_L

AW._AN_OPPORTUNITY_FOR_SO

ME_BRIEF_REMARKS_ON_THE_

CONCEPT_OF_FRAUD

Bauman, R. A., The interface of Greek and

Roman Law, 1996, Available at::

http://local.droit.ulg.ac.be/sa/rida/file/

1996/04.Bauman.pdf

Bengi Sayin, Korkmaz, Roma Hukuku'nda

Hile (Dolus) Kavrami, Temmuz,

Kirikkale University Journal of

Sciences, (2017) 7(2) Available at:

http://dergipark.gov.tr/download/articl

e-file/338039;

Bozkur, Gülnihal, Review of the ottoman legal system; Der Islam: Journal of The History and Culture of Middle East, (1994) 71(2), Available at: http://dergiler.ankara.edu.tr/dergiler/1 9/835/10563.pdf;

Cihan Osmanağaoğlu, Karahasanoğlu, Mecelle-i Ahkam-l Adliyye'nin Yürürlüğe Girişi ve Türk Hukuk Tarihi Bakımından Önemi; Sayi, (2011) Vol 2019, Available at: http://dergiler.ankara.edu.tr/dergiler/1 9/1682/17939.pdf

David, Ibbetson, Wrongs and Responsibility in Pre-Roman Law, The Journal of Legal History, (2004) 25(2), Available at:

http://faculty.uml.edu/Ethan_Spanier/ Teaching/documents/IbbetsonANEWr ongs.pdf

Dragusha, Musa, Kodi $i$ Hamurabit, një monument $i$ traditës juridike të njerëzimit, Avokatura, (2008) IV(7), Buletini I Odës së Avokatëve të
Kosovës. Available at: http://www.oakks.org/repository/docs/ AVOKATURA_Nr.7_687807_28624 6.pdf.

Hans Julius Wol, Commentary: Greek Legal History-Its Functions and Potentialities, Washington University Law Review, (1975), No. 2.

Hajdari, Egzonis, Erlüle, Fulya, Elements, types and consecuences of fraud according to Obligation Law - A comparative approach between legislation in Turkey and Kosovo, International Comparative Jurisprudence, (2018) 4(2), Available at:

http://dx.doi.org/10.13165/j.icj.2018.1 2.007

Kudret Ayiter, Türk Medeni Kanununun 40 Inci Yili, 4 Ekim 1966. Ankara Universitesi Hukuk Fakultesi Dergisi, Vol. 24, No. 1, Available at: http://dergiler.ankara.edu.tr/dergiler/3 8/336/3410.pdf

Lily Zakiyah Munir, General Introduction to Islamic Law. Kamali, (1991) 18, 1991, Available at: http://www.lfip.org/laws718/docs/lilypdf/Introduction_to_Islamic_Law.pdf . Mihaela, Miruna Tudoraşcu and Alba, Iulia, Paraschiv D. Ion - Good faith to conclusion of the sale, 2009, Available at:

http://www.uab.ro/reviste_recunoscute /reviste_drept/annales_12_2009/31tud orascu.pdf

Țuţuianu Ion, Legal regulation of the obligations in old romanian law, greek and roman, Studies and Scientific Researches Economics Edition, No. 16-17, 2012, Available at:: http://sceco.ub.ro/index.php/SCECO/a rticle/view/74/74 


\section{Regulations}

Türk Borçlar Kanunu, 1926, madde 23-31.

Available at:

http://www.tim.org.tr/files/downloads/ mevzuat/borclar_kanunu.pdf

Turkish Obligation Law - Kodi Nr. 818/1926.

Law in Obligational Relationships in Kosovo, Law Nr. 04/L-077, 19.06.2012.

The Code of Hammurabi, 05, 11, 13, 34, 103, 106, 107, 108, 109, 114, 155, 156, 265. Available at: https://www.google.com/url?sa=t\&rct $=\mathrm{j} \& \mathrm{q}=\&$ esrc $=\mathrm{s} \&$ source $=$ web $\& \mathrm{~cd}=2 \&$ ved=0ahUKEwiS0_2Nz6DYAhUPaQKHTamA_IQFgguMAE\&url=https $\% 3 \mathrm{~A} \% 2 \mathrm{~F} \% 2$ Fupload.wikimedia.org\% 2Fwikipedia\%2Fcommons\%2Ff\%2Ff 7\%2FCode_of_Hammurabi_\%252819 04\%2529.pdf\&usg=AOvVaw0zogb3 D3GxyIQITWxrlgN1

Zakon o Obligacionim Odnosima, Službeni list SFRJ. Br.29/78.

\section{Internets}

Andrea, Büchler, Introduction to Islamic and Middle Eastern Law FS16, Zurich 2016. Available at: https://www.rwi.uzh.ch/dam/jcr:00000 000-0bb9-0e00-ffff-

ffffb2e82aa8/HistoricalOverviewandS ources.pdf

Holden, George, Code of Hammurabi, the Important Laws of Our Time, November 2015. Available at: http://www.epcc.edu/HonorsProgram/ Student\%20Projects/M_ChavezNorth_Code\%20of\%20Hammurabi\%2 0the\%20important\%20laws\%20of\%2 0our\%20time\%20(APA).pdf

Mihai Olariu, Contracts In Roman Law, 2014, Available at: ftp://ftp.repec.org/opt/ReDIF/RePEc/r au/clieui/SP14/CLI-SP14-A9.pdf 